\title{
PRAKTIK PERDUKUNAN MENURUT TIGA PRASASTI PENINGGALAN KEDATUAN SRIWIJAYA ABAD KE 6 - 7 MASEHI
}

\author{
SHAMANISM PRACTICES ACCORDING TO THREE INSCRIPTIONS \\ OF THE KEDATUAN SRIWIJAYA IN THE 6th - 7th AD
}

\author{
Hot Marangkup Tumpal Sianipar, Abednego Andhana Prakosajaya, \\ Ayu Nur Widiyastuti \\ Departemen Arkeologi Fakultas Ilmu Budaya Universitas Gadjah Mada \\ Jalan Sosiohumaniora, No. 1, Bulaksumur, Yogyakarta 55281, Indonesia \\ E-mail: hot.marangkup.tumpal@mail.ugm.ac.id
}

DOI: $10.36424 / j p s b . v 6 i 2.186$

Naskah Diterima: 23 Juli 2020 Naskah Direvisi: 01 Nopember 2020 Naskah Disetujui: 02 Nopember 2020

\begin{abstract}
Abstrak
Praktik perdukunan banyak digunakan untuk berbagai macam kepentingan. Salah satunya ialah penggunaan santet (ilmu magis) dari seorang dukun. Ini dinilai sebagai tindakan yang merugikan dan membahayakan masyarakat. Praktik perdukunan memang sudah mengakar di Nusantara seperti terlihat pada prasasti-prasasti peninggalan Kedatuan Sriwijaya. Penelitian ini mengambil objek penelitian tiga prasasti peninggalan Kedatuan Sriwijaya, yakni prasasti Kota Kapur, Palas Pasemah, dan Telaga Batu. Penelitian ini bertujuan untuk membahas bentuk praktik dan sifat perdukunan dalam tiga prasasti peninggalan Kedatuan Sriwijaya. Penelitian yang termasuk ke dalam ranah kajian ilmu epigrafi ini menggunakan penalaran induktif. Metode penelitian yang bersifat deskriptif kualitatif. Penelitian terhadap tiga prasasti berangka tahun abad 6-7 $\mathrm{M}$ ini menunjukkan bahwa isi tiga prasasti ini mengandung kalimat-kalimat yang mengindikasikan adanya praktik perdukunan. Praktiknya adalah mencelakakan dan merugikan seseorang. Praktik ini beraliran hitam dan bersifat negatif sehingga dilarang oleh pemerintah Kedatuan Sriwijaya. Pelakunya akan mendapatkan kutukan dari raja sebagai hukuman.
\end{abstract}

Kata kunci: perdukunan, prasasti, Kedatuan Sriwijaya 


\begin{abstract}
The practice of shamanism is used for various purposes. One of which is the use of witchcraft (magic) from a shaman. It is considered as a harmful act and is endangering society. The practice of shamanism is indeed rooted in the archipelago, as seen in the inscriptions of Kedatuan Sriwijaya. This research takes three inscriptions in Kedatuan Sriwijaya, namely the Kota Kapur, Palas Pasemah, and Telaga Batu inscriptions as the object of research. The research aims to discuss the shamanism written in the three inscriptions of Kedatuan Sriwijaya. This epigraphy studies uses inductive reasoning accompanied by descriptive qualitative research methods. The results of the research on the three inscriptions of the Srivijaya Kedatuan which dates from the 6-7 century AD shows that the contents of these three inscriptions contain sentences that indicate the practice of shamanism. The practice of shamanism includes black magic. The purpose is to harm society so that this practice is prohibited by the Srivijaya Kingdom. The perpetrators will be punished with a curse from the king.
\end{abstract}

Keywords: shamanism, inscription, Kedatuan Srivijaya

\title{
PENDAHULUAN
}

Pada tahun 2019 lalu, isu perdukunan di tanah air sempat mencuat kembali sehingga menjadi perbincangan masyarakat ketika pemerintah menggagas dan menyetujui undang-undang tersendiri untuk menanggulangi kasus santet. Pasalnya, perkara ini dinilai sebagai tindak kejahatan yang merugikan dan menimbulkan keresahan di masyarakat seiring dengan maraknya isu ilmu hitam dari seorang dukun. Hal ini dapat dilihat pada Rancangan Revisi Kitab Undang-Undang Hukum Pidana (RKUHP) yang dibuat oleh Dewan Perwakilan Rakyat (DPR) bersama pemerintah, tepatnya dalam Pasal 252 serta disejajarkan dengan Paragraf 'Penawaran Bantuan untuk Melakukan Tindak Pidana'. Panitia Kerja (Panja) KUHP DPR menyetujui poin yang mengatur soal larangan bagi setiap orang yang menyatakan dirinya mempunyai ilmu hitam untuk melakukan tindakan negatif. Jika terbukti, orang tersebut akan dikenakan pidana tiga tahun penjara 
(Maharani, 2019). Tidak dapat dimungkiri meskipun saat ini manusia sudah hidup dalam era modern, masih terdapat masyarakat yang memercayai dukun sebagai sosok yang dapat dimintai jasanya untuk melakukan kepentingan tertentu. Dalam Kamus Besar Bahasa Indonesia Jilid V, dukun didefinisikan sebagai orang yang mengobati, menolong, orang sakit, memberi jampi-jampi (mantra, guna-guna, dan sebagainya). Konsep dukun sebenarnya memiliki banyak pengertian. Dalam Oxford English Dictionary disebut dengan shaman yang berasal dari bahasa Jerman schmane, orang-orang Rusia menyebutnya shaman, yakni seseorang yang dihormati karena memiliki kemampuan yang hebat, mampu memengaruhi, dan memotivasi, baik dalam kebaikan maupun keburukan. Dalam bahasa Sanskerta, ilmu perdukunan disebut dengan pramosadha. Istilah dukun kemudian digunakan secara bebas untuk menggambarkan banyak istilah yang sejenis yang berkembang di masyarakat, misalnya peramal, penyembuh, penyihir, pesulap, dan istilah sejenisnya (Nurdin, 2015:44).

Praktik perdukunan memiliki akar yang cukup panjang dalam sejarah umat manusia. Di Indonesia, ilmu hitam secara turun-temurun terus diwarisi hingga saat ini dukun masih populer bukan hanya di sisi masyarakat tradisional, melainkan juga di tengah lingkungan modern. Sekilas hal ini memang tampak ganjil, fenomena perdukunan yang sampai detik ini tidak dapat dibuktikan secara ilmiah justru tumbuh subur di tengah derasnya kemajuan teknologi pada masa sekarang. Praktik perdukunan tidak memiliki variabel yang jelas sehingga para pakar dari berbagai bidang belum dapat mengukur kebenaran maupun kesalahan metode yang digunakan (Kuntari dalam Ardani, 2013:32). Keberadaan dukun yang identik dengan kekuatan supranatural merupakan fenomena sosial yang kerap dipandang sebagai black magic sehingga dianggap menyeleweng dari norma oleh sebagian masyarakat. Meskipun begitu, praktik perdukunan masih memiliki peran yang signifikan bagi suatu kelompok masyarakat tertentu. Masyarakat Indonesia masih percaya terhadap hal-hal magis yang dinilai mendatangkan keuntungan baginya. Perilaku tersebut tampak dari upaya masyarakat yang mendatangi 
dukun (paranormal) untuk sekadar meramal nasib, meminta perlindungan dari hal buruk, mendatangkan rezeki, memikat lawan jenis, mendatangkan hal buruk bagi orang yang dibencinya, dan sebagainya (Arthani, 2015:32). Namun, sebagian masyarakat lain menilai praktik perdukunan sebagai sesuatu yang berada di luar akal sehat manusia sehingga mereka tidak memercayai hal-hal seperti ini. Menurut Daruputra dalam Nurdin (2015:43) penyebutan istilah dukun sering kali dihindari sehingga diganti dengan istilah yang bernada eufemistis, yaitu paranormal. Istilah dukun dianggap mengandung konotasi negatif karena di dalamnya terkandung makna penipuan, klenik, dan praktik yang tidak benar.

Tylor dalam Nurdin (2015:1) memandang animisme sebagai dasar pijakan bagi semua agama dan menjadi tahapan awal bagi proses evolusi dalam bidang keagamaan. Secara umum, penganut animisme percaya bahwa kekuatan gaib (supernatural) dapat menghuni binatang, tumbuhan, dan objekobjek lain secara alami. Kekuatan ini dibayangkan sebagai roh-roh atau jiwajiwa. Dr. Aris Fauzan, dosen Program Doktor Psikologi Pendidikan Islam Universitas Muhammadiyah Yogyakarta, dalam Focus Group Discussion tentang Klenikologi menjelaskan dari segi historis munculnya klenik-klenik yang terdapat di Indonesia. Ia menyebutkan bahwa Indonesia memiliki banyak sistem kepercayaan, seperti paham dinamisme, animisme, Buddha, Hindu, Islam, dan lain-lain di mana di dalamnya terdapat beragam aliranaliran kepercayaan seperti Darmo Gandul, Gatolotjo, dan lain-lain. Semua keyakinan tersebut merupakan kombinasi dari budaya lokal yang sudah terdapat sejak zaman dahulu dengan agama-agama yang datang kemudian (BHP UMY, 2019).

Studi mengenai praktik perdukunan secara umum telah cukup banyak dilakukan oleh para peneliti dan dikupas dalam berbagai tema yang ditulis dalam bentuk buku, skripsi, tesis, ataupun jurnal. Salah satunya ialah hasil penelitian milik Geertz yang berjudul The Religion of Java dalam Nurdin (2015:21) yang menjelaskan tentang praktik pengobatan melalui dukun yang menghasilkan tipologi dukun, yaitu dukun santri, dukun priyayi, dan dukun 
abangan. Tipologi ini didasarkan pada jenis keahlian dan kemampuan dukun dalam mempelajari ilmu dan cara mempraktikkan ketika mengobati klien. Penelitian Geertz ini menggunakan pendekatan etnografi berbasis antropologi budaya. Kendati penelitian ini dilakukan di Jawa, beberapa pandangan, prinsip dan konsep yang digunakan oleh Geertz mengenai dukun dapat digunakan dalam penelitian yang memiliki latar tempat di Sumatra seperti penelitian ini.

Sementara itu, Widya Sherliawati (2014) dalam skripsinya yang berjudul Kepercayaan Masyarakat terhadap Dukun: Studi Kasus di Lingkungan 5 Kelurahan Yukum Jaya Kecamatan Terbanggi Besar Kabupaten Lampung Tengah memberikan keterangan bahwa masih terdapat sekelompok masyarakat yang mendatangi dukun di Kelurahan Yukum Jaya Kecamatan Terbanggi Besar Lampung Tengah. Berdasarkan kepentingannya maka kepercayaan masyarakat terhadap dukun di Yukum Jaya meliputi komunitas dengan kepentingan hubungan harmonis, kepentingan kedudukan politik, dan kepentingan ekonomi (pedagang dan petani). Secara garis besar, terdapat beberapa penyebab masyarakat mempercayai dukun, yakni penyebab dari budaya masyarakat, kebijakan pemerintah, dan lemahnya pemahaman akan nilai dan norma keagamaan.

Studi lainnya dapat dilihat pada penelitian yang berpijak pada sosiologi kesehatan milik Yunita yang berjudul Pemanfaatan Pengobatan Dukun Magis dalam Upaya Penyembuhan Penyakit di Palembang dalam Nurdin (2015:22). Penelitian ini menggambarkan tentang motif orang yang datang ke dukun terkait penyembuhan penyakit dan konsultasi mengenai kehidupan di masyarakat Palembang. Penelitian ini cukup membantu peneliti dalam memperoleh gambaran tentang pengobatan melalui jalan perdukunan yang berada di bekas salah satu pusat wilayah Kedatuan Sriwijaya saat ini.

Salah satu bukti tertulis dari adanya praktik perdukunan pada zaman dahulu sejatinya dapat dilihat dari prasasti. Adapun menurut Williams dalam Izza (2019:110) kata prasasti berasal dari bahasa Sanskerta, yaitu prasasti yang dapat diartikan sebagai sanjungan atau pujian dan dalam arti lain dapat berarti 
pedoman, pembimbing, ataupun ancaman. Sedangkan, Mardiana dalam Izza (2019:110-111) menyebutkan bahwa arti prasasti yang dikenal sekarang ialah sumber tertulis yang dibuat dari bahan yang awet atau tahan lama, misalnya batu, logam, kayu, ataupun tulang binatang dan berisi informasi mengenai peristiwa penting tertentu misalnya penetapan tanah sima. Prasasti di Nusantara yang dibuat oleh kerajaan-kerajaan yang pernah berdiri pada masa Hindu-Buddha memiliki ciri khas yang dapat dilihat dari bahan, ornamen, isi, serta jenis aksara dan bahasa yang digunakan (Izza, 2019:110-111).

Berdasarkan pembacaan yang telah dilakukan oleh para peneliti sebelumnya melalui proses transliterasi, translasi, dan transkripsi terhadap beberapa prasasti peninggalan Kedatuan Sriwijaya seperti prasasti Kota Kapur, Palas Pasemah, dan Telaga Batu, diketahui bahwa pada ketiga prasasti kutukan ini terkandung tulisan yang memberitahukan adanya praktik perdukunan pada abad 6-7 M. Berdasarkan penelusuran terhadap beberapa penelitian terdahulu, sepemahaman penulis masih belum ada penelitian yang membahas mengenai perdukunan dengan melihat prasasti sebagai sumber datanya. Oleh sebab itu, pada artikel ini penulis berfokus untuk melihat praktik perdukunan yang terdapat pada prasasti-prasasti peninggalan Kedatuan Sriwijaya tersebut berdasarkan sudut pandang arkeologi, khususnya epigrafi dalam melihat bukti-bukti peninggalan berupa prasasti sebagai sumber data. Adapun masalah-masalah yang akan dibahas dalam artikel ini dapat dirumuskan sebagai berikut. Pertama, seperti apa praktik perdukunan yang terdapat dalam tiga prasasti peninggalan Kedatuan Sriwijaya? Kedua, apa sifat perdukunan yang terdapat dalam tiga prasasti peninggalan Kedatuan Sriwijaya?

\section{METODE PENELITIAN}

Penelitian ini menggunakan penalaran induktif dengan metode bersifat deskriptif yang diawali oleh observasi. Tujuan dari penalaran ini adalah untuk memperdalam pengetahuan mengenai suatu gejala tertentu atau mendapatkan pengetahuan baru mengenai gejala tersebut (Ginaris, 2019:186). Mengingat 
penelitian ini termasuk dalam ranah kajian ilmu epigrafi, maka tahapan observasi dalam penelitian ini dilakukan dengan mengobservasi hasil-hasil transliterasi dan translasi prasasti-prasasti yang termasuk ke dalam objek penelitian. Adapun objek penelitian ini adalah tiga prasasti yang berasal dari Kedatuan Sriwijaya, yakni prasasti Kota Kapur, Palas Pasemah, dan Telaga Batu. Hasil observasi berdasarkan sumber-sumber yang menyediakan translasi dan transkripsi isi prasasti, kemudian dijabarkan dan diolah hingga akhirnya ditarik kesimpulan yang dapat menjawab permasalahan penelitian. Selain itu, metode penelitian ini bersifat deskriptif kualitatif yang berusaha mendeskripsikan atau menggambarkan hasil penelitian berdasarkan faktafakta dari sumber data berupa hasil translasi dan transkripsi pembacaan prasasti-prasasti yang termasuk dalam objek penelitian ini.

\section{PEMBAHASAN}

Pengetahuan mengenai sejarah Kedatuan Sriwijaya sesungguhnya dapat dikatakan baru lahir pada permulaan abad ke-20 M. Sebagaimana diketahui bahwa Kedatuan Sriwijaya "ditemukan" oleh Coedes pada tahun 1918 di mana sebelum Coedes mengemukakan pandangannya, Sriwijaya dianggap sebagai sebuah nama raja. Akan tetapi, nama Sriwijaya kemudian mulai dikenal pada tahun 1918 sejak George Coedes menulis karangannya yang berjudul Le royaume de Srivijaya (Muljana, 2006:13-14). Karya Coedes ini merupakan sanggahan terhadap hasil pembacaan Prasasti Kota Kapur oleh H. Kern dan menegaskan bahwa Sriwijaya merupakan suatu negara atau kedatuan (Coedes dkk, 2014:1-3). Catatan perjalanan I-tsing pada $617 \mathrm{M}$ yang sudah diterjemahkan dalam Record and Memorie ditambah sumber berita Cina dari Dinasti Tang (618-907 M) menyebutkan lokasi Kerajaan Shih-Li-Fo-Shih (Kedatuan Sriwijaya) yang terletak di tepi pantai timur Sumatra bagian selatan dan berada di sebelah tenggara Melayu (Ismail, 2003:47). Letak ibu kota yang tidak disebutkan secara spesifik menimbulkan perdebatan pendapat mengenai letak ibu kota kedatuan yang dulunya pernah berjaya sebagai pusat studi agama Buddha Mahayana sekaligus menguasai 
jalur perdagangan maritim Selat Malaka. Berdasarkan Prasasti Kedukan Bukit yang berangka tahun 604 Ćaka (682 M) sebagai prasasti tertua peninggalan kedatuan ini, diperoleh informasi terkait Dapunta Hyang yang berangkat dari Minanga Tamwan menuju Muka Upang. Menurut pendapat Boechari (1993: A1 7-8), Minanga Tamwan terletak di wilayah sebelah timur Bangkinang. Sementara menurut Coedes dan Manguin, lokasi Muka Upang yang menjadi ibu kota Kedatuan Sriwijaya diartikan sebagai Palembang. Namun, tempat lain seperti Muaro Jambi (Sungai Batanghari) dan sekitar Candi Muara Takus (pertemuan Sungai Kampar Kanan dan Kiri) ditengarai pula sebagai ibu kota Kedatuan Sriwijaya (Boechari, 1978:27-30; Soekmono, 1978:75-76).

Selain Prasasti Kedukan Bukit, Kedatuan Sriwijaya juga meninggalkan prasasti-prasasti lain sebagai bukti peninggalannya. Beberapa di antaranya ialah prasasti-prasasti kutukan, seperti prasasti Kota Kapur, Palas Pasemah, dan Telaga Batu yang semuanya beraksara Pallawa dan berbahasa Melayu Kuno. Tersebarnya prasasti kutukan di berbagai wilayah Kedatuan Sriwijaya diasumsikan sebagai upaya untuk menjamin ketertiban daerah taklukkannya sekaligus memperkuat kedudukan Kedatuan Sriwijaya untuk melakukan ekspansi wilayah (Ismail, 2002:62). Peneliti Balai Arkeologi Sumatra Selatan, Retno Purwanti, menyebutkan bahwa sekitar 90\% prasasti di zaman Kedatuan Sriwijaya berisikan mengenai kutukan raja. Hal ini bertujuan untuk memaksa masyarakat supaya tunduk pada kesatuan (Riyadhana, 2019). Beberapa sumber menyebutkan bahwa isi ketiga prasasti ini sebagian besar sama (Suleiman dkk, 1978:38; Coedes dkk, 2014:155).

Perlu diketahui bahwa isi prasasti yang akan disajikan dalam artikel ini tidak dituliskan mulai dari pembuka sampai penutup isi prasasti, tetapi hanya berupa penggalan-penggalan kalimat yang berkaitan dengan praktik perdukunan sesuai dengan permasalahan penelitian. Hal ini sekiranya dapat memperjelas isi bahasan sehingga lebih efisien dan terarah.

\section{Prasasti Kota Kapur}

Prasasti ini ditemukan di Kota Kapur, sebelah utara Sungai Menduk, 
Pulau Bangka. H. Kern merupakan orang yang pertama kali meneliti prasasti ini pada tahun 1913. Penulisan pada batu prasasti ini dibuat dengan cara dipahat. Prasasti yang berbentuk obelisk dengan ukuran tinggi 1,77 m, lebar $32 \mathrm{~cm}$ di alas, dan $19 \mathrm{~cm}$ di puncaknya ini, berangka tahun $686 \mathrm{M}$. Dilihat dari jenis batu yang digunakan untuk prasasti ini dimungkinkan apabila batu tersebut bukan berasal dari pulau Bangka, melainkan didatangkan dari luar pulau Bangka karena di pulau ini sendiri tidak terdapat jenis batu tersebut (Coedes dkk, 2014:65). Prasasti ini berisi tentang kutukan-kutukan kepada mereka yang berbuat jahat, tidak tunduk, dan tidak setia pada raja.

\section{Bagian Teks Asli}

5. ...jaya tālu muaḥ ya di்an gotrasantānāãna. tathāpi savañakña yam vuatña jāhat. makalanit uram. makasākit. makagīla. mantrā gada viṣaprayoga. upuḥ tūva. tāmval.

6. Sarāìvat. kasīhan. vaśīkarana.ityevamādi. jāñan muah ya siddha. pulam ka iya muaḥ yam doșāña vuatña jāhat inan tathāpi nivunuh ya sumpah̆ tuvi mulam yam manu-

7. ruḥ marjjahāti. yam vātu nipratiștha ini tuvi nivunuh ya

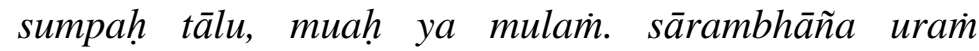
drohaka tida bhakti tida tatvārjjava diy āku, dhava vua-

8. tña nivunuh ya sumpah ini grañ kadāci iya bhakti tatvārjjava diy āku. dían di yam nigalarku sanyāsa datūa. śānti muah kavuatāña. dìan gotrasantānāñāa

Bagian Terjemahan

5. ...dihukum bersama marga dan keluarganya. Lagipula biar semua perbuatannya yang jahat; seperti mengganggu :ketenteraman jiwa orang, membuat orang sakit, membuat orang gila, menggunakan mantra, racun, memakai racun upas dan tuba, ganja,

6. saramwat, pekasih, memaksakan kehendaknya pada orang lain dan sebagainya, semoga perbuatanperbuatan itu tidak berhasil dan menghantam mereka yang bersalah melakukan perbuatan jahat itu; biar pula mereka mati kena kutuk. Tambahan pula biar mereka yang menghasut orang

7. supaya merusak, yang merusak batu yang diletakkan di tempat ini, mati juga kena kutuk; dan dihukum langsung. Biar para pembunuh, pemberontak, mereka yang tak 
berbakti, yang tak setia pada saya, biar pelaku perbuatan tersebut

8. mati kena kutuk. Akan tetapi jika orang takluk setia kepada saya dan kepada mereka yang oleh saya diangkat sebagai datu, maka moga-moga usaha mereka diberkahi, juga marga dan keluarganya...

(Sumber: Coedes dkk, 2014:67-69)

Pada Prasasti Kota Kapur, terlihat bahwa terdapat istilah menggunakan mantra dan pekasih. Dalam Kamus Besar Bahasa Indonesia Jilid $V$, kata mantra memiliki arti sebagai perkataan atau ucapan yang memiliki kekuatan gaib (misalnya dapat menyembuhkan, mendatangkan celaka, dan sebagainya). Secara sekilas, istilah ini dapat memiliki arti yang positif maupun negatif. Kemudian, kata pekasih memiliki makna guna-guna untuk membangkitkan rasa cinta kasih. Apabila dikaitkan dengan isi prasasti di atas maka dapat dikatakan bahwa kedua istilah ini dianggap sebagai perbuatan yang buruk (negatif) karena pelaku perbuatan seperti menggunakan mantra dan pekasih akan terkena kutuk sebagai hukuman. Kata dukun sering dikaitkan dengan seseorang yang memiliki kekuatan linuwih, erat akan mantra-mantra, dan urusan gaib. Kemudian, terdapat dukun yang melayani dengan duduk di tempatnya sambil membaca mantra-mantra.

Dukun yang berada di tempat sambil membaca mantra-mantra seperti memanggil dewa-dewa dan roh-roh (Nurdin, 2015:48). Masykur (2020:2-3) menuturkan bahwa terdapat banyak macam jenis mantra, yakni mantra pengasihan, mantra kekebalan, mantra perlindungan, mantra pengobatan, mantra pengusir jin, dan lain-lain. Ketika akan memulai aksinya, dukun biasanya akan melafalkan mantra terlebih dahulu. Dalam hal ini, diasumsikan bahwa mantra adalah semacam password atau keyword dan sebagainya yang mungkin saja memiliki daya magis sebagai bahasa yang mampu mengantarkan maksud dari si pelafal, dalam hal ini dukun, menuju apa yang diharapkan oleh dukun, lalu menjadi kenyataan.

Makna mantra bergantung pada tujuan dari mantra tersebut dipergunakan. Suatu mantra dapat dimaknai sebagai mantra santet jika mantra 
tersebut dipergunakan dalam ritual santet dan suatu mantra tidak dapat dimaknai sebagai mantra santet jika digunakan untuk tujuan yang lain. Dukun juga sering kali diminta oleh orang yang datang ke dukun tersebut untuk membantu dalam hal masalah jodoh (Sherliawati, 2014:2). Dengan demikian, dapat diambil kesimpulan bahwa memang terdapat praktik perdukunan berdasarkan Prasasti Kota Kapur di mana praktik perdukunan tersebut merupakan perbuatan yang buruk dan tidak boleh dilakukan. Saksono (2007:65) menuturkan bahwa terdapat berbagai macam praktik perdukunan di mana jenis yang paling ganas, yakni tenung, jangges, dan santet yang semuanya ini bertujuan untuk membunuh korbannya dengan cara memasukkan benda-benda asing ke tubuh korban melalui medium roh-roh jahat yang dihadirkan lewat mantra-mantra yang diucapkan sang dukun.

Dalam Prasasti Kota Kapur, praktik perdukunan tampak dilarang oleh pihak yang mengeluarkan prasasti atau dalam konteks ini merupakan pemerintahan Kedatuan Sriwijaya itu sendiri. Konteks praktik perdukunan dalam prasasti ini merupakan perdukunan yang merugikan sesama penduduk dan masyarakat Kedatuan Sriwijaya. Prasasti Kota Kapur ini juga menekankan bahwa siapa saja yang tidak berbakti pada Kedatuan Sriwijaya akan memperoleh kutuk. Hal ini mengindikasikan bahwa Kedatuan Sriwijaya sendiri memiliki kekuasaan magis untuk mengawasi penduduknya sehingga tidak menutup kemungkinan kekuatan ini berasal dari perdukunan itu sendiri.

Secara garis besar, Prasasti Kota Kapur ini tidak hanya mengindikasikan adanya penggunaan dukun antar penduduk dari berbagai kalangan di wilayah bawahan atau wilayah yang menyusun konsep mandala Kedatuan Sriwijaya tempat ditemukannya prasasti ini, tetapi juga mengindikasikan bahwa pemerintahan Kedatuan Sriwijaya sendiri memegang kekuatan magis yang dalam prespektif tertentu dapat dikategorikan sebagai perdukunan maupun hanya sebagai sarana untuk melakukan kontrol sosial terhadap penduduknya. 
Prasasti Palas Pasemah

Prasasti ini ditemukan pada tahun 1958 di tepi Sungai Pisang atau Way Pisang yang merupakan anak Sungai Sekampung di daerah Palas Pasemah, Lampung Selatan. Menurut analisis paleografi yang dilakukan oleh Boechari, prasasti ini diduga berasal dari akhir abad ke-7 $M$ dan memperingati ditaklukannya daerah Lampung Selatan oleh Kedatuan Sriwijaya di mana pada prasasti ini termuat kutukan (Poesponegoro \& Notosusanto, 2008:79). Batu prasasti ini sebagian tertanam dalam tumulus (gundukan tanah dan batu) serta berukuran tinggi $0,75 \mathrm{~m}$ dan $0,5 \mathrm{~m}$ pada bagian alas (Boechari, 1978:19). Prasasti ini terdiri atas tiga belas baris dan hanya terukir pada satu sisi dengan konten yang hampir sama dengan Prasasti Karang Brahi di Jambi (Boechari, 2018:363).

Bagian Teks Asli

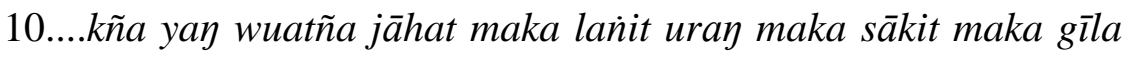
mantrāganda wișaprayoga ūpuh tūwa tā (mwal sa)

11. ..rāmwat kasīhan waśīkaraṇa ityewamādi jānan muah ya siddha pulay ka ya muah yay doșāña wu (a)

12. ..tña jāhat inan. ini gray kadāci ya bhakti tatwa ārjjawa di yāku dìan di yay nigalarkku sanyāsa datūa śānti muaḥ (ia)...

Bagian Terjemahan

10. ...orang yang berniat buruk, (seperti orang yang) membuat orang menghilang, membuat orang sakit, membuat orang gila, mengucapkan kata-kata magis (jampi-jampi), meracuni orang dengan upas dan tuba, dengan racun yang terbuat dari akar-akaran dan semua jenis (tanaman)

11. merambat, menjalankan ilmu pengasih (supaya orang jatuh cinta), melecehkan orang dengan guna-guna, biarlah mereka dijatuhkan dari keberuntungan, dan dibenci masyarakat

12. karena sangat berlaku buruk. tetapi mereka patuh dan setia kepadaku, dan mereka kunobatkan menjadi datuk akan memperoleh (segala) keberuntungan...

(Sumber: Suleiman dkk, 1978:20-22; Boechari 2018:363-365)

Pada Prasasti Palas Pasemah terdapat istilah mengucapkan kata-kata magis (jampi-jampi); menjalankan ilmu pengasih (supaya orang jatuh cinta); 
dan melecehkan orang dengan guna-guna. Adapun dalam Kamus Besar Bahasa Indonesia Jilid $V$, magis disebut sebagai perbuatan atau tindakan yang bersifat magi sehingga kata magis memiliki hubungan dengan kata magi. Kemudian, masih dalam Kamus Besar Bahasa Indonesia Jilid V, kata magi memiliki arti sesuatu atau cara tertentu yang diyakini dapat menimbulkan kekuatan gaib dan dapat menguasai alam sekitar, termasuk alam pikiran dan tingkah laku manusia. Jadi, magi adalah sesuatu hal yang terkandung di dalam mantra atau jampi dan dapat dipadankan dengan magic.

Menurut Lévi-Strauss dalam Nurdin (2015:36), magi adalah serangkaian teknik untuk memengaruhi sesuatu yang gaib dan kekuatankekuatan supernatural secara langsung dan otomatis sehingga timbul kekuatan gaib. Penggunaan magi terdiri dari dua jenis, yaitu magi putih untuk menolong orang dan magi hitam untuk mencelakakan orang. Sementara itu, ada juga yang menyebutkan bahwa magi sesungguhnya terdiri atas empat warna (Masruri, 2010; Herniti, 2012), yakni (1) magi hitam yang berefek negatif dan untuk mengirim penyakit, kesialan (mencelakakan), ataupun membunuh; (2) magi merah yang berupa pelet dengan karakter keras untuk memikat lawan jenis, tetapi ada unsur dendam dan mempermalukan korban.; (3) magi kuning yang berupa pelet dengan karakter lembut atas dasar kasihsayang untuk tujuan dinikahi dan bisa juga untuk meningkatkan kewibawaan menghadapi bawahan atau masyarakat umum; dan (4) magi putih untuk penyembuhan serta untuk menangkal ketiga magi lainnya.

Pada Prasasti Palas Pasemah dapat disimpulkan bahwa ketiga istilah yang telah disebutkan merupakan bentuk dari magi hitam karena perbuatanperbuatan tersebut dianggap sangat buruk sehingga siapa saja yang melakukannya akan terkena hukuman berupa dijauhkan dari keberuntungan dan dibenci masyarakat. Hal ini lalu diperkuat juga dengan adanya guna-guna yang digunakan untuk melecehkan. Guna-guna identik dengan santet yang erat kaitannya dengan praktik perdukunan di mana pada umumnya dilakukan dengan melantunkan mantra (jampi). Tidak ada cara untuk membuat santet sebagai suatu tindak pidana secara hukum ataupun tuntutan hukuman ganti 
rugi karena tidak ada prosedur formal untuk melakukannya dalam kasus apapun (Saksono, 2007:68). Hal ini disebabkan tidak adanya bukti yang mendukung praktik tersebut dan biasanya hanyalah desas-desus yang belum tentu kebenarannya. Prasasti Palas Pasemah menunjukkan adanya hukuman berupa sanksi sosial bagi mereka yang melakukan dan mencari praktik perdukunan. Sanksi sosial berupa penjauhan dari masyarakat menunjukkan bahwa penggunaan praktik perdukunan dan mereka yang menggunakan jasa dukun di periode ini tidak diperkenankan untuk menjadi bagian dari masyarakat. Di sini, tampak jelas bahwa penggunaan dukun baik dalam ranah masyarakat luas sangat ditentang dan harus menanggung konsekuensikonsekuensi tertentu. Selain sanksi sosial, mereka yang menggunakan ilmu magis akan dijauhkan dari keberuntungan. Hal ini mengarah pada sanksi keagamaan atau sanksi yang bersifat abstrak. Sanksi-sanksi ini menjadi indikasi bahwa Kedatuan Sriwijaya dengan konsep mandalanya sangat melarang diterapkannya praktik perdukunan bagi para penduduknya di wilayah bawahannya.

\section{Prasasti Telaga Batu}

Prasasti yang bagian atasnya dihiasi tujuh kepala kobra dan di bagian bawahnya bercerat ini ditemukan di Dusun Telaga Batu, Palembang Timur, Sumatra Selatan. Penulisannya dilakukan dengan memahat tipis yang berisi 28 baris tulisan serta memiliki tinggi $118 \mathrm{~cm}$ dan lebar $148 \mathrm{~cm}$. Prasasti yang diperkirakan berangka tahun $7 \mathrm{M}$ ini berisi peringatan atau ancaman bagi siapa saja, baik pejabat kedatuan maupun rakyat jelata, yang tidak patuh terhadap perintah raja dan dianggap sebagai prasasti terlengkap berdasarkan isi dan makna tersirat di dalamnya karena mewakili keseluruhan prasastiprasasti kutukan lainnya yang dikeluarkan Dapunta Hyam (Kartakusuma, 1993:23-24). Adapun Prasasti Telaga Batu merupakan prasasti yang sejauh ini menyediakan informasi dalam bentuk teks paling ekstensif di Kedatuan Sriwijaya. Dari segi paleografis, prasasti ini memiliki keidentikan dengan 
gaya aksara yang digunakan dalam Prasasti Kota Kapur. Bahkan, prasasti ini mungkin ditulis oleh penulis atau citralekha yang sama (Casparis, 1956:15)

\section{Bagian Teks Asli}

8. ...athawā marcorakāra hīna madhpamottamajāti. yadi makalanit tāmwa pam prajā niraksāhku.athawā makatālu muặ uram kalpita pürwa katālu muạ̣ña uram ārambha kadātuanku niwunuḥ kāmu sumpaḥ, tuwi mulam dari kämu...

10. yākan ka śatrunkku ka dātu paracakșu lai niwunuh kāmu sumpaḥ// athawā kadāci kāmu māti malūn maṃruruā athawā kāmu larīya mamlarīya lai kāmu nicāri lai marwuat=nicāri parddātuan

11. mañalit mas mani malūn maṃruruā kadātuanku. marwuddhi sāraṇa ri lai kāmu. urạn wukan wwaidika tahūña kāmu marwuat sākit. tīda kāmu. marppādah dari hukun tuhāìku. niwunuḥ kāmu sumpaḥ. kāmu tuwi nigalarmāmu marsaṃjñ̄̄wuddhi kulamāmu mañ-caru

12.. ìku kāmu āda pātra dañan darah niwunuh kāmu sumpaḥ, tuwi mulam tāhu kāmu sthānāña śatrunku lai nipinañ̃a maka śrìyantra dikata luar samsthāna tīda kāmu... marppādah $d y=\bar{a} k u$ dihulu tuhāìku niwunuh kāmu sumpah, tathāpi kāmu...

13. di samaryyādapatha di wanuā wā̀nun dy=āku. tīda kāmu marppādạ̣ niwunuh kāmu sumpaḥ.ini makalańit=prāna urạ̣ marūpa bhasma waidimantraprapoga.tīda āhārā dari samayanku rüpinahku kușta kasīhan waśtīkaraṇa lai. Kadāci kāmu...

14. marwuddhisāraṇa mara maryyāda. yathā waśīkaraṇa. tīda makagīla makalanit prāṇāña. athawā wuatña tāhu kāmu di deśa. tìda ya kamulam $d y=\bar{a} k u$ di hulun tuhāńku. niwunuh kāmu sumpặ athawā cihna dìri kāmu lai marwuat yạ̣ wuat jāhat ini.i.i prati...

15. ti dirīña... di kāmu. niwunuh kāmu sumpah. athawā mulam dari kāmu lai yam sanyāsa datūa. sanyāsa.... nda. sanyāsa

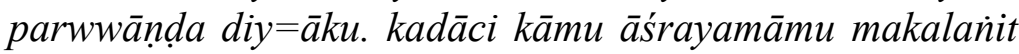
wuatāña sata...

16. tah niwunuh kāmu sumpah. athawā mulam āda uram dari kāmu..... sawañakña kriyā-karmmakāryyakarādi....i niwunuh kāmu sumpah. athawā mulam kadāci àda.... prakārāña tīda niwunuh kāmu sumpah

17. kāmu sumpah...... 
Bagian Terjemahan

8. ....ataupun berusaha mencuri, terutama orang-orang di sekelilingku tidak terkecuali golongan dan turunan, baik keturunan rendah, menengah maupun tinggi, dukun (pembuat racun) terutama bila yang berusaha meracuni (sihir) mereka akan gila, kamu akan terbunuh kutukan. Jikalau

10. karena mereka akan segera terbunuh oleh kutukanku. Atau mereka akan mati sebelum berhasil membawa hasil curiannya ke luar istana, tidak akan sempat meminta tolong karena terbunuk kutukan dan laknatku. Jikalau kamu

11. diam-diam menyembunyikan (korupsi) persediaan emas dan harta kekayaan kedatuan, atau bekerjasama dengan dukun istana untuk membuat sakit kerabat kedatuan atau tidak tunduk pada pemerintahku, kamu akan terlaknat dan terbunuh kutukanku. dan jikalau kamu

12. membuat persekongkolan di antara keluargamu untuk menjatuhkanku dengan upacara sihir (?) kamu akan terbunuh kutukanku. Terlebih lagi jikalau kamu akrab/intim dengan segala sesuatu kegiatan musuh-musuhku, terutama para dukun sihir yang berusaha meracuni, menentang pemerintahanku dan tidak tunduk padaku, kamu akan terkena kutuk. Juga kamu yang

13. bersekongkol dengan penguasa-penguasa daerah (rajavazal) untuk melawan kekuasaanku dan tidak tunduk padaku, akan terkena dan terbunuh kutuk. Atau raja-raja vazal itu bersengkongkol dan mempunyai fikiran jahat (gila) untuk menjatuhkanku kekuasaanku melalui kekuatan guna-guna, sihir lainnya. Jikalau ada di antara kamu (rajaraja vazal) .... (teluh), mantra, meneropong keadaanku tanpa sepengetahuanku dengan menggunakan kustha, pekasih...

14. yang memanfaatkan kekuasaannya untuk membunuh, atau diam-diam membujuk dan bersekongkol untuk mengadakan coup d'etat, mempengaruhi fikiran, gerakan dan semacamnya di wilayah ke- kuasaanku, kamu akan dibunuh kutukan. Jikalau di antara kamu bersukutu berbuat jahat terhadapku,

15. maka kalian beserta seluruh antek-antekmu akan hancur dan binasa oleh kutukan ini. Juga mereka yang mencoba menggunakan kekuasaanku sebagai Datu atau berusaha sebagai Datu atau parwanda, membuat keonaran........... kamu akan terkena kutukan ini. Atau jikalau ada di antara kamu yang sengaja mengatur sekarang, masa lampau, dan masa yang akan datang (masa kemudian) 
16. kamu akan terkena kutukan ini. Atau jikalau ada di antara kamu yang di bawah pengawasan..... padaku ......sebanyak tindakan yang dilakukan di masa sekarang, lampau, dan yang akan datang... kamu akan terbunuh oleh kutukan. atau yang melalui tangan lain,....... hubungan mereka, kamu akan terbunuh oleh

17. kutukan ini.......

(Sumber: Kartakusuma, 1993:19-23)

Pada Prasasti Telaga Batu terdapat beberapa istilah yang diperkirakan sebagai praktik perdukunan, antara lain dukun (pembuat racun) terutama bila yang berusaha meracuni (sihir); terutama para dukun sihir yang berusaha meracuni; menjatuhkanku kekuasaanku melalui kekuatan guna-guna, sihir lainnya; dan jikalau ada di antara kamu (raja-raja vazal)... (teluh), mantra, meneropong keadaanku tanpa sepengetahuanku dengan menggunakan kustha, pekasih. Menurut Mulyana dalam Nurdin (2015:157), banyak penduduk di negara wilayah Asia dan Afrika yang masih percaya bahwa penyakit yang mereka alami disebabkan oleh roh-roh jahat atau kekuatan magis yang dihasilkan melalui ilmu sihir. Menurut Lévi-Strauss dalam Kasniyah (1999:15) ilmu sihir merupakan ilmu hitam yang berkonotasi destruktif dengan tujuan kematian. Sihir merupakan tindakan yang jahat karena dengan sengaja mencelakakan orang lain. Sihir selalu dipraktikkan karena alasan khusus seperti marah, iri, benci, balas dendam, dan lain sebagainya. Hal tersebut dapat dilakukan dari jarak jauh tanpa melakukan kontak fisik sehingga menyebabkan penderitaan bagi si korban. Adanya halhal buruk yang terjadi pada seseorang dihubungkan sebagai bentuk perbuatan dukun di mana pada istilah di atas terlihat raja atau dalam hal ini pemerintah Kedatuan Sriwijaya sepertinya sudah mengetahui bahwa peristiwa terkena racun (sihir) merupakan perbuatan dari seorang dukun. Hal ini sejalan dengan pandangan Townsend dalam Nurdin (2015:38) bahwa seorang dukun dapat berkomunikasi langsung dengan roh-roh dan dapat memerintahkan roh-roh tersebut untuk melakukan tindakan magis kepada tubuh seseorang lewat mantra-mantra yang diucapkan. 
Unsur mantra yang menonjol menekankan bahwa praktik yang dilakukan oleh dukun berlandaskan pada nilai-nilai yang magis. Dukun dipandang sebagai yang paling mengetahui tentang mantra yang dapat menjadi perantara atau penghubung antara dunia nyata dengan dunia gaib (Sobary, 1997:138). Dalam Prasasti Telaga Batu, diketahui terdapat satu pihak yang menyandang identitas kedatuan yang melakukan kontrol atas wilayahnya cara menyumpah atau mengutuk seseorang yang dianggap tidak patuh dan membahayakan kedatuannya. Sementara itu, pihak yang diperingatkan dan diancam dengan sumpah tersebut ialah semua lapisan masyarakat di wilayah kedatuannya (Ismail, 2002:60). Tak terkecuali putra raja, para pejabat, para menteri, raja vasal, panglima, dan masyarakat lainnya yang berkhianat dengan cara menggunakan praktik perdukunan. Dalam hal ini santet (teluh) yang bertujuan untuk mencelakakan raja demi merebut kekuasaan. Perbuatan ini termasuk ke dalam perbuatan negatif sehingga perbuatan tersebut akan dibalas dengan terbunuh oleh kutukan sang raja. Atas dasar uraian tersebut, maka dapat diasumsikan bahwasanya sihir cenderung dipergunakan kepada kerabat, rekan, dan kenalan. Tentu saja, dukun yang dimintai pertolongan bisa saja bukan merupakan kenalan dari si korban. Namun, pencetus tindakan ini sebagian besar selalu berasal dari orang yang dekat dengan si korban (Saksono, 2007:65).

Penggunaan kutuk bagi mereka yang berani membahayakan, merugikan, atau mengancam seorang pemimpin Kedatuan Sriwijaya mengindikasikan bahwa raja sendiri memiliki kekuatan magis. Dapat diasumsikan sang raja sudah memiliki kekuatan spiritual yang lebih tinggi dari pada dukun yang akan digunakan lawan untuk menyihirnya. Selain itu, hal ini juga mengindikasikan bahwa praktik perdukunan tidaklah dilarang selama digunakan untuk tujuan-tujuan yang positif seperti menyembuhkan orang sakit.

Menurut Geertz dalam Kasniyah (1999:7) pemenang pertempuran antara dukun dalam medan mistik akan dapat mengembalikan magi tersebut kepada lawannya dan lawannya pun akan sengsara seperti yang semula 
diharapkan oleh dukun yang menang. Dalam kasus tersebut para dukun yang kalah tidak akan terkena efek sihirnya, tetapi pencetus di balik tindakan tersebutlah yang terkena imbasnya. Kemungkinan kedua adalah pemanfaatan orang yang memiliki kemampuan dalam ilmu magis untuk melindungi raja Kedatuan Sriwijaya dari ancaman santet atau teluh sehingga dapat dikatakan bahwa raja sendiri sejatinya menggunakan praktik perdukunan. Dilihat dari lokasi prasasti yang berada di ibu kota Kedatuan Sriwijaya dan isinya yang lebih ekstensif, mengarah pada kutukan bagi mereka yang berani melawan perintah maupun melakukan hal-hal buruk pada raja Kedatuan Sriwijaya, Hal ini mengindikasikan bahwa praktik perdukunan dan niatan-niatan buruk setidaknya pada masa ketiga prasasti ini dikeluarkan tampaknya lebih dominan dijumpai di ibu kota tempat raja bertakhta. Adapun pelarangan penggunaan dukun dan pemberian kutuk selain yang telah dilakukan oleh raja mengindikasikan adanya upaya kontrol sosial secara abstrak melalui penyebarluasan informasi yang termuat dalam prasasti bahwa hanya kekuatan dan kutuk seorang raja yang memiliki kuasa penuh di seluruh Kedatuan Sriwijaya sehingga barang siapa berani bertindak negatif terhadap seorang raja terutama mereka yang dekat dengan raja itu sendiri akan memperoleh ganjaran magis yang setimpal. Di sini, dapat dilihat bagaimana dukun merupakan suatu ancaman nyata bagi seorang raja sekaligus suatu sosok yang sangat berguna bagi raja itu sendiri. Perdukunan atau setidaknya dalam hal ini kekuatan magis dimanfaatkan oleh Kedatuan Sriwijaya untuk menjaga tatanan kelas yang ada dengan mengutuk mereka yang berani mengganggu raja sebagai pimpinan tertinggi dalam sistem sosial dan pemerintahan.

Dari penjelasan di atas, diketahui bahwa praktik perdukunan di Kedatuan Sriwijaya kala itu berupa praktik yang dinilai sebagai perbuatan negatif. Hal ini dibuktikan dengan adanya larangan untuk menggunakan praktik perdukunan yang bersifat mencelakakan pada prasasti-prasasti kutukan Kedatuan Sriwijaya. Adapun contoh-contoh praktik perdukunan yang terdapat dalam tiga prasasti tersebut adalah perbuatan sihir untuk meracuni, penggunaan santet untuk mengganggu jalannya pemerintahan, 
memakai pengasih agar lawan jenis jatuh cinta padanya, dan memakai gunaguna untuk melecehkan seseorang. Seperti yang telah dijelaskan sebelumnya bahwa tidak selamanya praktik perdukunan bersifat mencelakakan. Akan tetapi, juga terdapat praktik perdukunan yang bertujuan untuk menolong. Dalam tiga prasasti tersebut, tidak terdapat penggunaan praktik perdukunan yang bertujuan untuk menolong.

Adanya beberapa penggalan kalimat yang berkaitan dengan praktik perdukunan pada tiga prasasti tersebut tampaknya mampu untuk menjelaskan bahwa praktik perdukunan kala itu cukup populer bahkan digunakan dalam ranah politik Kedatuan Sriwijaya. Terdapat perbedaan pendapat para ahli terkait apakah prasasti-prasasti kutukan ini ditujukan kepada penduduk di wilayah ibu kota Sriwijaya atau justru kepada daerah-daerah yang berhasil ditaklukan Sriwijaya sebagai bentuk perluasan kekuasaan (Muljana, 2006:155-156). Namun demikian, dapat ditafsirkan bahwa praktik perdukunan sudah berkembang pada abad 6-7 M. Praktik perdukunan ini tidak hanya marak ditemui di lingkungan masyarakat umum dan penduduk Sriwijaya pada umumnya, namun juga dapat dijumpai sebagai suatu ancaman di lingkungan elite Kedatuan Sriwijaya bahkan hingga pada tingkatan pemimpin tertinggi atau raja dari Kedatuan itu sendiri. Dalam hal ini, para citralekha atau pembuat prasasti menjadi sarana untuk menunjukan bahwa pemimpin Kedatuan Sriwijaya tidak dapat dicelakai atau ditipu oleh pihak manapun karena kekuasaan magis yang dimilikinya. Hal ini mengindikasikan bahwa sejatinya pemimpin kedatuan itu sendiri menggunakan ilmu magis atau beliau sendiri merupakan seorang dukun yang tidak dapat disakiti oleh ilmu magis maupun melalui tindakan yang buruk terhadapnya.

Selain itu, praktik perdukunan berhubungan erat dengan adanya penggunaan mantra. Dalam kasus ini, belum dapat dijelaskan mengenai cara lebih mendalam yang dilakukan oleh seorang dukun dalam menjalankan tugasnya untuk mencelakakan seseorang. Peran dukun dalam kehidupan sosial pun belum dapat diketahui secara pasti. Menurut Nurdin (2015:223) terdapat dukun yang memiliki kemampuan untuk menjadi pemimpin umat, 
namun juga terdapat yang berperan sebagai medioker. Pada dasarnya seorang dukun tidak selalu murni bekerja sebagai dukun, terkadang juga bekerja sebagai petani, pedagang, dan pegawai negeri sehingga pekerjaan dukun hanya sebagai sambilan. Apabila memperhatikan penampilan fisik seorang dukun maka tidak jauh berbeda dengan masyarakat biasa. Para dukun tidak selalu mengenakan baju serba hitam, cincin batu di hampir semua jari, dan wujud yang menyeramkan seperti imajinasi umum tentang dukun (Bakti, Alwi, \& Saifullah, 2018:116). Data dari ketiga prasasti yang telah dibahas juga kurang menunjukkan secara pasti peranan seorang dukun maupun bagaimana dukun dan ilmu magis itu sendiri bekerja seperti prosedur dan ritual apakah yang harus dilalui untuk mewujudkan keinginan maupun mencelakakan seseorang. Akan tetapi, ketiga prasasti yang telah dibahas telah menunjukkan gambaran yang representatif tentang eksistensi perdukunan sebagai suatu ancaman sehingga para citralekha yang bekerja di bawah perintah raja kedatuan Sriwijaya harus menyebarluaskan konsekuensikonsekuensi bagi mereka yang melakukan praktik perdukunan di wilayah Kedatuan Sriwijaya.

Adanya pembahasan oleh negara mengenai Pasal 252 RUU KUHP yang mengatur tentang santet merupakan bentuk respons negara terhadap kondisi masyarakat Indonesia yang sebagian masih memercayai hal-hal mistis (Satriadi, 2020:147). Pada umumnya di kehidupan sehari-hari, terlihat ada semacam bentuk ketidaknyamanan bagi sebagian orang untuk menunjukkan praktik sosial yang dilakukannya ini di depan sesamanya dan publik. Praktik ini diibaratkan sebagai ruang privat yang ingin ditutup rapat-rapat dari jangkauan pengetahuan orang lain. Artinya, ada rasa malu ketika orang lain mengetahui bahwa orang tersebut telah mendatangi dukun untuk mengutarakan maksud dan rencananya. Hal ini dapat dikatakan bahwa praktik perdukunan merupakan budaya paradoks di dalam komunitas masyarakat. Praktik sosial ini hidup di tengah masyarakat, namun malu untuk diakui keberadaannya. Sudah menjadi rahasia umum memang bahwa praktik perdukunan masih terus-menerus hidup. Saking berkembangnya, para 
pelanggan dukun pun datang dari berbagai kalangan, mulai dari masyarakat pedesaan hingga masyarakat perkotaan serta warga biasa hingga tokoh-tokoh elite (Bakti, Alwi, \& Saifullah, 2018:113\&124).

Terdapat beberapa faktor penyebab yang dapat menjelaskan fenomena ini. Menurut Dermawan (dalam Bakti, Alwi, \& Saifullah, 2018:113), eksistensi dukun dalam masyarakat terjadi karena kehadiran dukun sangat signifikan bagi masyarakat. Selain itu, beberapa dukun juga tidak menetapkan tarif khusus kepada orang yang datang di mana semua didasarkan atas kerelaan hati orang tersebut untuk memberikan imbalan terhadap jasa dukun. Tidak hanya itu saja, Ardani (dalam Bakti, Alwi, \& Saifullah, 2018:113) menyimpulkan bahwa eksistensi dukun dan metode tradisionalnya masih hidup di tengah era modern sekarang ini karena masyarakat masih memercayai praktik perdukunan dan hasilnya terbukti manjur. Demikian pula penelitian yang dilakukan Zulfa (dalam Bakti, Alwi, \& Saifullah, 2018:113) yang menyatakan bahwa keberadaan dukun di lingkungan masyarakat didukung oleh biaya jasa dukun yang relatif murah (terjangkau), adanya pengaruh dari sekitarnya, serta keyakinan dan kepercayaan turun-temurun dalam keluarga. Terkait dengan ilmu yang diperoleh, terdapat anggapan bahwa ilmu perdukunan diberikan secara alami oleh Sang Pencipta sementara ada yang berpandangan bahwa ilmu ini dapat dipelajari (ngelmu) melalui ahlinya.

Praktik perdukunan pada masa Sriwijaya yang cenderung bersifat mencelakakan dan merugikan (negatif) di mana sudah dijelaskan sebelumnya ternyata masih tetap dapat dijumpai hingga masa kini. Bakti, Alwi, \& Saifullah (2018:118-119) menjelaskan bahwa saat ini masih banyak orang yang memanfaatkan jasa dukun untuk melampiaskan kekecewaan atau ketidaksenangannya pada seseorang. Ketika mereka tidak suka dengan orang lain karena memiliki masalah tertentu atau dianggap sebagai saingan dan musuh, mereka akan menggunakan dukun untuk menghancurkan atau bahkan membunuh orang yang diincar. Hal ini terjadi karena mereka merasa tidak mampu menghadapi secara langsung orang yang dianggap sebagai musuh 
tersebut sehingga meminta bantuan kepada dukun dengan kekuatan gaibnya (Safitrf, 2013:20). Sebaliknya, ada juga orang yang justru meminta kepada dukun untuk menjadikan lawan jenisnya menjadi senang dan jatuh cinta kepadanya. Kasus-kasus seperti ini umumnya dilakukan oleh orang-orang yang suka memaksakan kehendaknya pada orang lain. Adapun biasanya air atau pasir merupakan medium utama bagi dukun dalam mengekspresikan kesaktiannya. Tidak hanya itu, dalam arena kompetisi seperti perlombaan olahraga lazim ditemukan pihak-pihak yang memanfaatkan jasa dukun untuk membantu timnya memenangkan pertandingan. Misalnya, pemain bintang yang mewakili tim lawan tiba-tiba mengalami sakit perut sehingga tidak mampu melanjutkan pertandingan padahal pemain bintang tersebut sebelumnya dinyatakan sehat (Bakti, Alwi, \& Saifullah, 2018:120).

\section{PENUTUP}

Praktik perdukunan merupakan kepercayaan masyarakat terhadap kekuatan supernatural yang tidak dapat dilepaskan dari kondisi masyarakat Indonesia sejak masa Hindu-Buddha dan praktik ini telah memercayai kekuatan gaib pada benda-benda di luar nalar manusia. Lebih jauh lagi, salah satu bukti tertulis adanya praktik perdukunan tertera dalam prasasti-prasasti peninggalan Kedatuan Sriwijaya, yakni Prasasti Kota Kapur, Palas Pasemah, dan Telaga Batu. Melihat isi dari tiga prasasti yang berangka tahun mulai dari abad 6-7 $\mathrm{M}$ ini diketahui bahwa terdapat kalimat-kalimat yang menunjukkan adanya praktik perdukunan. Isi prasasti-prasasti ternyata memberikan informasi bahwa pemerintah Kedatuan Sriwijaya memasukkan praktik perdukunan sebagai perbuatan yang dilarang sehingga pelakunya akan mendapat kutuk sebagai hukuman dari raja. Pelarangan ini dikarenakan praktik perdukunan yang dilakukan memiliki sifat aliran hitam di mana tujuannya adalah untuk mencelakakan seseorang, seperti menggunakan santet untuk menjatuhkan pemerintahan dan menggunakan pekasih supaya lawan jenis tertarik kepada dirinya. 
Sikap tegas Kedatuan Sriwijaya yang melarang praktik perdukunan magi hitam cukup mirip dengan kondisi tahun 2019 lalu di mana pemerintah Indonesia menggagas RUU KUHP dan terdapat Pasal 252 RUU KUHP yang bertujuan menanggulangi santet yang terjadi di masyarakat. Dapat dikatakan bahwa praktik perdukunan beraliran hitam termasuk ke dalam praktik yang bersifat negatif (tidak baik) sehingga Kedatuan Sriwijaya dan pemerintah Indonesia tidak menginginkan adanya santet dan para pelakunya harus dihukum. Namun, lain halnya dengan praktik berupa magi putih yang bersifat menyembuhkan. Praktik seperti ini dapat tetap ada di kehidupan masyarakat. Adapun praktik-praktik perdukunan berupa magi hitam sebagaimana tertulis dalam tiga prasasti peninggalan Sriwijaya ternyata masih terus berlangsung hingga zaman yang sudah modern saat ini. Hal ini menunjukkan bahwa dukun masih terus memiliki peranan yang besar dalam kehidupan masyarakat.

\section{UCAPAN TERIMA KASIH}

Penulis mengucapkan terima kasih kepada semua pihak yang telah memberikan saran dan masukan terhadap penulisan artikel ini, yakni kepada Drs. Tjahjono Prasodjo, M.A. dan Dr. Mimi Savitri, M.A. sebagai dosen Departemen Arkeologi Universitas Gadjah Mada. Penulis juga berterima kasih kepada para peneliti terdahulu yang telah menyediakan sumber transliterasi, transkripsi, dan translasi berbagai prasasti yang digunakan sebagai sumber data dalam artikel ini di mana sumber tersebut diolah dan digunakan sebagai referensi. 


\section{DAFTAR PUSTAKA}

Ardani, Irfan. 2013. "Eksistensi Dukun dalam Era Dokter Spesialis". Dalam Lakon: Jurnal kajian sastra dan budaya, Vol. 1, No. 2, hlm. 28-33.

Arthani, Ni Luh Gede Yogi. 2015. "Praktik Paranormal dalam Kajian Hukum Pidana di Indonesia". Dalam Jurnal Advokasi, Vol. 5, No. 1, hlm. 3040.

Bakti, Indra S., Alwi, \& Saifullah. 2018. "Eksistensi Dukun di Tanah Gayo". Dalam Jurnal Sosiologi USK, Vol. 12, No. 2, hlm. 111-127.

BHP UMY. 2016. Pertumbuhan Klenik di Indonesia Dinilai Sangat Subur. Diakses dari http://www.umy.ac.id/pertumbuhan-klenik-di-indonesiadinilai-sangat-subur.html pada 12 Juni 2020.

Boechari. 1978. "An Old Malay Inscription of Srivijaya at Palas Pasemah (South Lampung)". Dalam Pra Seminar Penelitian Sriwijaya. Jakarta: Proyek Penelitian dan Penggalian Purbakala Departemen P \& K.

Boechari. 1993. "Hari Jadi Kota Palembang Berdasarkan Prasasti Kedukan Bukit". Dalam Sriwijaya dalam Perspektif Arkeologi dan Sejarah. Palembang: Provinsi Sumatera Selatan.

Boechari. 2018. Melacak Sejarah Kuno Indonesia Lewat Prasasti. Jakarta: KPG.

Casparis, J. G. de. 1956. Selected Inscriptions from the 7th to the 9th Century A.D. Bandung: Masa Baru.

Coedes, George dkk. 2014. Kedatuan Sriwijaya. Depok: Komunitas Bambu.

Ginaris, Lengkong Sanggar. 2019. "Pergeseran Letak Permakaman Belanda di Kota Surabaya dari Abad 18 Hingga Awal Abad 20“. Dalam Berkala Arkeologi, Vol. 39, No. 2, hlm. 183-200.

Herniti, Ening. 2012. "Kepercayaan Masyarakat Jawa Terhadap Santet, Wangsit, dan Roh Menurut Perspektif Edwards Evans-Pritchard".

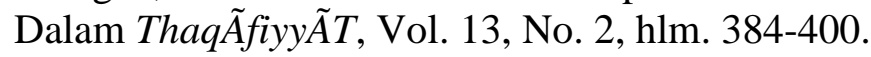

Ismail, H. M. Arlan. 2002. Periodesasi Sejarah Sriwijaya: Bermula di Minanga Komering Ulu Sumatera Selatan berjaya di Palembang berakhir di Jambi. Palembang: Unanti Press.

Izza, Nainunis Aulia. 2019. "Prasasti-prasasti Sapatha Sriwijaya: Kajian Panoptisme Foucault". Dalam Titian: Jurnal Ilmu Humaniora, Vol. 03, No. 01, hlm. 110-123. 
Kamus Besar Bahasa Indonesia Jilid V. 2016. Diakses dari https://kbbi.kemdikbud.go.id/ pada 12 Juni 2020.

Kartakusuma, Richadiana. 1993. "Dapunta Hiyam Sri Jayanasa: Kajian Atas Makna dari Prasasti Telaga Batu”. Dalam Amerta, Vol. 13, No. 3, hlm. 17-32.

Kasniyah, Naniek. 1999. Sistem Kesehatan Non-Barat Sistem Personalistik: Fenomena Sosial Pada Pengalaman Individu "Diserang" Santet. Yogyakarta: Fakultas Sastra Universitas Gadjah Mada.

Maharani, Tsarina. 2019. RUU KUHP Masih Muat Pasal Santet, Dukun Hitam Dibui 3 Tahun Penjara. Diakses dari https://news.detik.com/berita/d-4683961/ruu-kuhp-masih-muat-pasalsantet-dukun-hitam-dibui-3-tahun-penjara/1 pada 17 Juni 2020.

Masruri, A. 2010. The Secret of Santet. Jakarta: Visimedia.

Masykur, Zein Muchamad. 2020. Makna Mantra Santet dalam Buku The Secret of Santet Analisis Perspektif Filsafat Bahasa Languange Games Ludwig Wittgeinstein. Skripsi. Salatiga: Jurusan Aqidah dan Filsafat Islam Fakultas Ushuluddin Adab dan Humaniora Institut Agama Islam Negeri.

Muljana, Slamet. 2006. Sriwijaya. Yogyakarta: PT LKiS Pelangi Aksara Yogyakarta.

Nurdin, Ali. 2015. Komunikasi Magis: Fenomena Dukun di Pedesaan. Yogyakarta: PT LKiS Printing Cemerlang.

Poesponegoro, Marwati Djoened \& Nugroho Notosusanto. 2008. Sejarah Nasional Indonesia II. Edisi Pemutakhiran. Jakarta: Balai Pustaka.

Riyadhana, Bagas Putra. 2019. Mengungkap Jejak Sejarah Prasasti 'Kutukan' Kedatuan Sriwijaya. Diakses dari https://kumparan.com/urbanid/mengungkap-jejak-sejarah-prasastikutukan-kedatuan -sriwijaya-1rKJXeYpQhV pada 12 Juni 2020.

Safitrf, Ikha. 2013. "Kepercayaan Gaib dan Kejawen Studi Kasus pada Masyarakat Pesisir Kabupaten Rembang”. Dalam Sabda, Vol. 8, hlm. 18-28.

Saksono, Ignatius Gatut. 2007. Paranormal: Peran dan Tanggung Jawab Moralnya. Yogyakarta: Yayasan Pustaka Nusantara. 
Satriadi, 2020. "Delik Santet dalam Konstruksi Rancangan Kitab Undang". Dalam Jurnal Al-Adalah: Jurnal Hukum dan Politik Islam, Vol. 5, No. 2, hlm. 135-149.

Sherliawati, Widya. 2014. "Kepercayaan Masyarakat terhadap Dukun: Studi Kasus di Lingkungan 5 Kelurahan Yukum Jaya Kecamatan Terbanggi Besar Kabupaten Lampung Tengah". Skripsi. Bengkulu: Jurusan Sosiologi Fakultas Ilmu Sosial dan Ilmu Politik Universitas Bengkulu.

Sobary, Mohamad. 1977. Fenomena Dukun dalam Budaya Kita. Jakarta: PT Pustaka Firdaus.

Soekmono, R. 1978. "Sekali Lagi Tentang Lokalisasi Sriwijaya". Dalam Pra Seminar Penelitian Sriwijaya. Jakarta: Proyek Penelitian dan Penggalian Purbakala Departemen P \& K.

Suleiman, Satyawati dkk. 1978. Pra Seminar Penelitian Sriwijaya. Jakarta: Proyek Penelitian dan Penggalian Purbakala Departemen P \& K. 